\title{
Correlation of Fried Snacks Intake with Free Radicals and Obesity in Elementary School Children
}

\author{
Ummi Hidayati, Albiner Siagian, Etti Sudaryati \\ Faculty of Public Health, University Sumatera Utara, Indonesia \\ alza.aqilah84@gmail.com
}

\begin{abstract}
The increase in degenerative disease and obesity is mainly caused by lifestyle, eating pattern, and activities. Obesity can cause death throughout the world. It affected 349 million children and adolescents (5-19 years old) in 2016. The objective of this research was to find out the correlation of fried snacks intake with free radicals, and obesity. The research used quantitative method with cross sectional design. The samples were 56 students of elementary school, taken by using purposive sampling technique. The result of the research showed that 50 students (84.7\%) had normal free radicals in their bodies and 9 students (15.3\%) had high free radicals. There were 11 students (18.6\%) who were obese and 48 students (81.4\%) were not. The result of pearson correlation test showed that there was significant correlation of the number of energy, carbohydrates, fat contribution in fried snacks with free radical content (MDA analysis) at respective p-value of 0.004, 0.005, and 0.026. The result of correlation test showed that there was the correlation between fat nutrient intake in fried snacks and obesity $(p=0.012)$. Reducing consuming fried snacks is one of the ways to decrease the effect of free radicals in school children's bodies.
\end{abstract}

Keywords: fried Snack; Free Radical; Malondialdehyde; antioxidant

\section{Introduction}

Indonesia experiences an increase in the prevalence of degenerative disease each year and $26.4 \%$ of them died. Death caused by cardiovascular, especially coronary heart disease and stroke, is assumed to be increasing to 23.3 million in 2030 (Kemenkes, 2013). Besides that, scientific data indicate that the increase in degenerative diseases such as cancer, diabetes mellitus, coronary heart diseases today are caused by free radicals from food and beverages consumed daily.

The data from the World Health Organization (WHO) on the condition of nontransmitted disease in Indonesia in 2014 revealed that $71 \%$ of mortality was caused by non-transmitted diseases (WHO, 2014). These non-transmitted diseases have become the assignment and burden for the Government because, based on the data from JKN in 2015, the Government had to finance the non-transmitted diseases at the cost of about $23.9 \%$ for health service. The trend of non-transmitted diseases which tended to increase in the South-east Asia in 2011 indicated the proportion of mortality caused by non-transmitted diseases was 55\% more than transmitted diseases. The trend of mortality caused by nontransmitted diseases in Indonesia increased from 37\% in 1990 to $57 \%$ in 2015. It is estimated that the increase in non-transmitted diseases will continue, along with the change in life behavior such as eating pattern with imbalanced nutrition, lack of physical activity, smoking, and so on.

Reused cooking oil or repeated heating is allegedly the cause of free radicals in food and will give the effect of children's health, either in the short term or in the long term. During the process of frying the cooking oil will undergo various chemical reactions such as hydrolytic reaction, oxidation, isomerization, and polymerization. For example, cooking oil heated above 2000C will compose polymer, and unsaturated molecule will compose ring bundle. The process of frying using a tool made of iron can also stimulate fat oxidation. This condition can cause the decrease in the quality of cooking oil, indicated by murky cooking oil, bias index, acid number, iodine number, polymer compound, and free 


\section{A. Snacks}

Snacks which are sold by sidewalk vendors or in another term it is called street food, according to FAO (Food Association Organization) is defined as food and beverages prepared and sold by sidewalk vendors along the street and in other crowded places and are directly eaten or consumed without any processing or preparing. According to the Decree of the Minister of Health of the Republic of Indonesia No. 942/Menkes/SK/XII/2003, snacks are food and beverages which are processed by the vendors at their stands and/or served as fast food for the buyers food servers, restaurants, and hotels. From the above definition, it is found that snacks are food and beverages sold at public places, crowded places and usually served in a very short time with cheap price and affordable. Snacks with various types can also found to be sold cheaply around schools.

\section{B. Free Radicals}

Many researches have found that free radical can influence human health, especially those who live in urban areas. According to Halliwell and Gutteridge (1999) who cited the opinion of Chalid (2008), free radical is molecule which loses one electron or has electron which is not in pairs. Non-paired electron will continuously take another electron from the other molecules so that the new molecules will become new free radicals. The reactive nature of the molecules will continuously search for their electron mates which will cause negative effect on human health. Free radicals which take electron from DNA can cause the change in DNA structure do that mutant cells appear. Mutation which lasts long can cause cancer.

Free radicals can also plays their role in the process of growing old in which the reaction of free radical initiation in mitochondria can cause Reactive Oxygen Species (ROS) to be produced. Free radicals can be produced from body metabolism and external factors such as cigarette smoke, result of ultraviolet radiation, chemical substance in food, and pollution.

According to Suryohudoyo (2000) who cited from the opinion of Khairunnisa (2016), oxidative status constitutes the balance between production and reactive molecular exposure (radical compound) and anti-oxidant defense. This radical compound occurs as long as oxidative metabolism is normal as the result of radiation oxygen exposure, infection, chemical substance, and the other environmental factors. In human beings, free radicals can enter the body, and one of them is from the types of food which is consumed.

Fried snacks which is processed with deep frying method in which the entire food is soaked in cooking oil during the frying so that the food becomes crunchy. This process of deep frying can cause various chemical reactions such as oil hydrolytic, oxidation, cyclization, and polymerization. Chalid, et. al., (2008) point out in his research that free radical content in the cooking oil of frying snack sidewalk vendors indicates high free radical content in the day time. Free radical can damage lipid and form lipid peroxides which yield malondialdehyde (MDA) content.

Makryani, et. al.(2014) point out that MDA content in the subjects of being fond of fried food tends to be high and consuming antioxidant food and cincau hijau (Cyclea barbata) drink has significant influence on decreasing MDA content in the blood of the subjects. High free radical compound which is not balanced with antioxidant in the body can damage body tissues and DNA.

Analysis on MDA is the analysis on free radicals indirectly and has fairly high sensitivity and can easily be applied in determining the number of formed free radicals. 
Analysis on free radicals directly is very difficult to be done due to them the body. Free radicals which have been formed are often used as markers to assess oxidative stress. Measurement of marker content in the body can show pathological condition in a person's body. Excessive free radicals will increase lipid peroxidation so that MDA in the body can be influenced by many things, among others the content of lipid peroxidation in which MDA is the last product. Besides that, it can also be influenced by decomposition of amino acids, complex carbohydrate, pentose, hexoses, and biosynthesis prostaglandin. MDA is formed as the result of the degradation of

hydroxyl $(\mathrm{OH})$ free radicals toward unsaturated fatty acid which will be transformed to be very reactive radicals.

The process of composing MDA ca be explained as follows: oxygenated free radicals $\left(\mathrm{O}_{2}\right)$ is produced through enzymatic and non-enzymatic. Body cells which can compose oxygenated free radicals and $\mathrm{H}_{2} \mathrm{O}_{2}$ are polymorph nuclear, monoxide, and macrophage. MDA content (Dixon, 1998) used spectrometry in normal blood plasma of 0.2-0.7 $\mu \mathrm{mol} / 1$ to find out its oxidative status, and it is categorized as high when its value is $>1.7 \mu \mathrm{mol} / \mathrm{l}$ (Khairunnisa, 2016).

The composed free radicals will react with SOD (superoxide dismutase) and $\mathrm{Cu}^{+2}$ ion will become $\mathrm{H}_{2} \mathrm{O}_{2} . \mathrm{H}_{2} \mathrm{O}_{2}$ is mostly produced in mitochondria and microsomes and has the ability to penetrate cells. As a body resistance system, $\mathrm{H}_{2} \mathrm{O}_{2}$ can be changed to become $\mathrm{H}_{2} \mathrm{O}_{2}$ and $\mathrm{O}_{2}$ by catalyst enzyme. This peroxide hydrogen is a strong oxidant since it can react with various compounds. In oxidative stress, free radicals are composed excessively. The same is true to $\mathrm{H}_{2} \mathrm{O}_{2}$ so that body protective system cannot neutralize all of the composed free radicals (Janero, 1990; Halliwell \& Gutteridge, 2000).

\section{Obesity}

Obesity is an abnormal condition or excessive fat accumulation in the adipose tissues which is widespread so that they can disturb health. It can also be defined as the unbalance between the calories which enter the body and the number of calories which secrete (WHO, 2016). Obesity can occur when the number of fatty cells increases in one's body. The increase in body weight will bring about the increase in fatty acid content. Based on the idea of Irawan (2013) who cited the idea of Yagi, et. al., (1994), obesity constitutes a condition of high lipid concentration stored in adipose tissues. Unsaturated fatty acid in the cells will compose lipid peroxide. This condition can also occur as the result of free radicals in the body such as liver organ. The problem of obesity is a complex one which affects almost all ages, from children, adolescents, and adults. It is defined that when Body Mass Index (BMI) is more than 30, and it can be called overweight when BMI is more than 25. Prihantini and Jahari (2005) in Rachmi; Li; Baur (2017) point out that obesity in a 6-9 year-old child is caused by the habit of consuming fried snacks ( $>4$ times a week).

\section{Research Method}

The research used quantitative method with cross sectional design. It was conducted at SD Negeri Number 060812, located on Jalan STM, Medan Amplas Sub-district. The laboratory of LPPT, the Faculty of Medicine, University of Sumatera Utara was used to analyze MDA (Mondialdehyde) from August, 2018 until February, 2019. The population was 209 students of SD Negeri Number 060812, and 56 of them were used as the samples, 


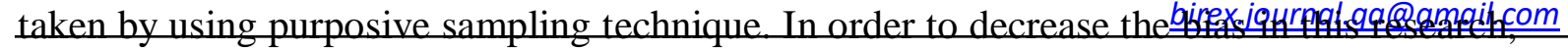
the researcher used inclusion criteria as follows:

- Grades IV, V, and VI Students;

- They did not consume any types of medicine and vitamins.

- They were not sick or affected by any infections.

The urine samples for analyzing MDA in this research were taken during their waking up in the morning by removing the first urine and the last urine in some millimeters and collecting the urine in between. The urine was expected to be able to describe the condition of the whole oxidative stress in the body (Wibowo, 2013; Weitner et.al., 2016). Gathering the data included:

1. The data on the nutrients fried snacks were obtained from food recall of 24 hours which were done twice, not successively, in order to get the data on intake (household measurement)

converted into calorie and gram units in which the values of energy, protein, and fat were calculated by using nutria-survey program;

2. The data of free radicals were obtained by analyzing the MDA in the laboratory by using spectrometry;

3. The data on obesity were obtained by measuring the respondents' body weight and height, using a digital scale and microcopies. Their BMI was then calculated ad adjusted to BMI/Age).

\section{Discussion}

The respondents were Grades IV, V, and VI students. There were 40 female students (67.8\%) and 19 male students (32.2\%). The number of Grade IV students was 25 (42.4\%), the number of Grade V students was 13 (22\%), and the number of Grade VI students was $21(35.6 \%)$. The result of measuring the respondents showed that 11 of them (18.6\%) were obese and 48 of them $(81.4 \%)$ were not. The result of the research also showed that 50 students $(84.7 \%)$ had normal free radicals in their bodies and 9 of them $(15.3 \%)$ had high free radicals.

Table 1. Distribution of Respondents' Characteristics

\begin{tabular}{lcc}
\hline \multicolumn{1}{c}{ Characteristics } & $\mathrm{n}$ & $\%$ \\
\hline Grades & & \\
a. IV $(8-9$ years $)$ & 25 & 42.4 \\
b. V $(9-10$ years $)$ & 13 & 22.0 \\
\hline \multicolumn{1}{c}{ Characteristics } & $\mathrm{n}$ & $\%$ \\
\hline c. VI $(11-12$ years $)$ & 21 & 35.6 \\
Total & 59 & 100 \\
Sex & & \\
a. Males & 19 & 32.2 \\
b. Females & 40 & 67.8 \\
Total & 59 & 100 \\
a. Obesity & 11 & 18.6 \\
b. Non-Obesity & 48 & 81.4 \\
\hline
\end{tabular}


Free Radicals (MDA

Analysis)

\begin{tabular}{lrr} 
a. Normal & 50 & 84.7 \\
b. High & 9 & 15.3 \\
Total & 59 & 100 \\
\hline
\end{tabular}

Pearson correlation test was used for statistical analysis. The result of Pearson test in the variable of the number of energies in fried snacks with free radical content in the respondents' bodies showed that $\mathrm{p}$-value $=0.004$ which value was smaller than 0.05 which indicated that there was significant correlation between the number of energies in fried snacks and free radical content.

The strength of the correlation between the variable of the number of energies in fried snacks with free radical content was $r=0.365$ which indicated that the strength of the correlation between the two variables was weak. The direction of positive correlation had the meaning that the higher the value of the number of fried snacks toward daily food, the higher the value of free radicals in the respondents' bodies.

The result of Pearson correlation test of the carbohydrate of fried snacks with free radicals through the analysis of MDA showed that $\mathrm{p}$-value $=0.005$ which was less than 0.05 which indicated that there was significant correlation between the two variables. Thevalue of 0.363 indicated that the strength of the correlation between the carbohydrate of fried snacks and the free radical content was weak. In the carbohydrate metabolism in human beings in general, the split carbohydrate will be absorbed in the small intestine (ileum) in the form of monosaccharide and brought by blood flow to liver. In the liver, monosaccharide which undergoes synthesis yields glycogen, oxidation becomes $\mathrm{CO}^{2}$, and $\mathrm{H}_{2} \mathrm{O}$ or is released to be brought by blood flow to the body organs which needs it. Monosaccharide synthesis involves superoxide anion and hydroxyl to yield energy and can yield free radicals in liver. The more the number of carbohydrates consumed from fried snacks, the more the work of liver in metabolism, and if the combustion is not equalized with physical activity, more free radicals will be yielded.

This research on the protein of fried snacks consumed by elementary students with free radical content had $\mathrm{p}$-value $=0.186$ which indicated that $\mathrm{p}$-value $>0.05$ so that there was no significant correlation between the protein of fried snacks and free radical content. The strength of the correlation between the two variables could be seen from the r-value of 0.186 which indicated that the correlation was weak. It was assumed that the number of proteins in fried snacks helps only fulfill the need for protein of the students in their daily life so that low protein content in their bodies were not excessively bound with free radicals which were reactive and unstable; therefore, free radicals have short life span. The other characteristics of free radicals were oxidizing and reducing; therefore, accumulation of free radicals in cells can cause the damage of cell components such as fatty cells, protein, carbohydrate, and nucleate acid. Excessive free radicals will oxidize the process of growing older in cell membrane and cause the process of growing older related to the modification of oxidative proteins.

Pearson correlation test, used to find out the correlation of fat in fried snacks in daily food with free radical content (MDA analysis) was $\mathrm{p}$-value $=0.026$ or $\mathrm{p}$-value was less than 0.05 which indicated that there was significant correlation between the variable of the contribution of fatty fried snacks on daily food with free radical content in the elementary school students. The strength of correlation was $r$-value $=0.289$ in which its correlation 
strength was between 0.2 and 0.4 which indicated the correlation streirextion consumed fatty fried snacks tended to be high because the frying process using deep frying method (the whole fried snacks were soaked in the cooking oil) will cause the fried snacks consumed by the children to have higher fat content. Another reason why free radical content was high in the body was that the process of frying used cooking oil continuously and repeatedly. Fat is bio-molecule which is vulnerable to the attack of free radicals. Protein and nucleate acid are more resistant to free radicals so that it is less possible that successive and quick reaction to occur. The attack of free radicals against protein is very rare except they are very extensive. It only occurs when the radicals are able to accumulate (it is rare in normal cells) or when the damage is focused on a certain area in protein.

According to Paramesha S, et., al. (2011) in Fariya, AK and Dias (2018), MDA is an important marker used to find out lipid per oxidation and to assess the level of oxidative stress. Lipid membrane and lipid which circulates lipoprotein such as Low Density Lipoprotein (LDL) can interact with Reactive Oxygen Species (ROS) which yield lipid per oxidation as the cause of the damage of cell membrane. The result of Pearson correlation test among the variables presented in Table 2 below showed as follows:

Table 2. Correlation of Nutrient Intake from Fried Snacks with Free Radicals

\begin{tabular}{lcc}
\hline \multirow{1}{*}{ Variables } & \multicolumn{2}{c}{ Correlation Coefficient } \\
\cline { 2 - 3 } & $\mathrm{r}$ & $p$ \\
\hline nber of Energies & 0.365 & 0.004 \\
ck Carbohydrate & 0.363 & 0.005 \\
ck Protein & 0.359 & 0.186 \\
ck Fat & 0.289 & 0.026 \\
\hline
\end{tabular}

The result of correlation between the number of energies of fried snacks and obesity, using Pearson correlation test was $p$-value $=0.219>0.05$ which indicated that there was no significant correlation between the two variables. Correlation test had the value of the correlation strength or $\mathrm{r}=0.163$ which indicated that the correlation between the number of energies of fried snacks and obesity was weak. This could seen from the value of correlation strength in $\mathrm{r}$-value $=0.0-<0.2$.

The result of the research on the correlation of carbohydrate nutrient intake in fried snacks with obesity in the variable of carbohydrate of fried snacks was p-value $=0.214>$ 0.05 which indicated that there was no significant correlation between carbohydrate of fried snacks and obesity in the elementary school children. The $r$-value $=0.164$ indicated that the correlation strength between the two variables above was very weak.

Pearson correlation test was used to find out the correlation of protein intake in fried snacks consumed by the elementary school children with obesity. The result of the test showed that $\mathrm{p}$-value $=0.680$ which indicated that there was no significant correlation between the two variables since $\mathrm{p}$-value $>0.05$. Meanwhile, the correlation strength of the two variables, between the protein of fried snacks and obesity was very weak since r-value $=0.055$ located between 0.0 and $<0.2$.

The result of Pearson correlation test on the correlation between fat consumed from 


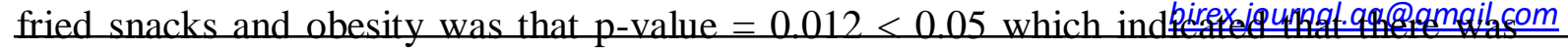
significant correlation between the contribution of fat in fried snacks to daily food and obesity. The r-value $=0.326$ which indicated that the correlation strength between the two variables was weak. The correlation direction of the two variables was positive in which the bigger the contribution of fat in the fried snacks to daily food, the bigger the opportunity for the incidence of obesity.

Table 3. Correlation between Nutrient Intake of Fried Snacks and Obesity

\begin{tabular}{lcc}
\hline \multirow{2}{*}{ Variables } & \multicolumn{2}{c}{ Correlation Coefficient } \\
\cline { 2 - 3 } & $\mathrm{R}$ & $p$ \\
\hline nber of Energies & .163 & 0.219 \\
ck Carbohydrate & .164 & 0.214 \\
ck Protein & .153 & 0.680 \\
ck Fat & .326 & 0.012 \\
\hline
\end{tabular}

\section{Conclusion}

The conclusion of the research was that there was significant correlation of the number of energies of fried snacks, carbohydrate, and fat in the fried snacks with free radical content (MDA analysis). Consuming fried snacks with high content of carbohydrate, fat, and energy could potentially increase free radical content in the bodies of the elementary school children. Besides that, fat content in snacks, especially in fried ones, had the correlation with obesity. Te

consumption of fried snacks had contributed to the incidence of obesity in the elementary school children.

It is recommended that

1. The students' parents always remind their children of healthful snacks and avoid consuming fried snacks excessively and take their own snacks from home.

2. The children consume fresh fruit and vegetables which contain Vitamin $\mathrm{C}$ as antioxidant in order to safeguard against free radicals.

\section{References}

Chalid, Yadial, Sri., Muawanah, Anna., Jubaedah, Ida., 2008. Analisa Radikal Bebas Pada Minyak Goreng Pedagang Kaki Lima (Analysis of Free Radicals on Street Food Cooking Oil). Jurnal Valensi Volume 1 No 2, May, 2008

Djatmiko, Erni. 2000. Proses Penggorengan dan Pengaruh Terhadap Sifat Fisika Kimia Minyak dan Lemak (Frying Process and Effects on the Physical Properties of Chemical Oil and Fat) . unpublicized. Agricultural Industry Department, the Faculty of Agricultural Technology, IPB

Depkes RI. 2003, Keputusan Menteri Kesehatan Republik Indonesia Nomor 942/Menkes/SK/VII/2003/Tentang Pedoman Persyaratan Hygiene Sanitasi Makanan Jajanan. Jakarta

Fariya, AK. Dias, Bina F. 2018. Study of oxidative stress biomarkers in Obese Children. International Journal of Reseach in Medical Science 2018 Oct, 6 (10): 3335 - 3339. 

Maharastra. India

Halliwell B and Gutteridge JMG. 1999. Free Radical in Biology Medicine: Oxford University Press. Ed. 3.

Irawan, Rico. 2013. Hubungan Obesitas Terhadap Kadar Malondealdehid (MDA) Plasma Pada Mahasiswa Program Study Pendidikan Dokter Uin Syarif Hidayatullah Jakarta (Relationship of Obesity to Plasma Levels of Malondealdehyde (MDA) in Uin Syarif Hidayatullah Medical Education Study Program Students Jakarta). Thesis. UIN Jakarta

Janero DR. 1990. Malondialdehyde ant thiobarbituric acid-reactivity as diagnostic indexes of lipid-peroxidative tissue-injury Free Radic.Biol.Med.9 : ACTA UNIVERSITATIS UPSALIESIS UPPSALA

Khairunnisa, Nova. 2016. Hubungan Kebiasaan Merokok, Aktifitas Fisik, Konsumsi Gula, Dan Status Gizi dengan Kadar Malondialdehide (MDA) dan Glukosa Darah Pada Orang Dewasa (Relationship between Smoking Habits, Physical Activity, Sugar Consumption, and Nutritional Status with Malondialdehyde (MDA) and Blood Glucose Levels in Adults). Thesis. Graduate School, IPB. Bogor

Kemenkes, 2013. Riset Kesehatan Dasar 2013. Available from: https://tirto.id/penyakitkardiovaskular-pembunuh-nomor-satu-ckvS, accessed on Oct. 30, 2017

Makaryani, Inti: Amaliya, Leli; Novi, R.R ; Karina. I.P; Desy. D.A. 2014. Pengaruh Pemberian Pangan Antioksidan Terhadap Kadar Malondialdehid Plasma Mahasiswa Penyuka Gorengan (The Effect of Antioxidant Feeding on Malondialdehyde Plasma Levels on Fried Enthusiasts). Jurnal Gizi Klinik Indonesia Vo. 10 No. 4 April, 2014. Public Nutrition Department, the Faculty Human Ecology, IPB. Bogor

Nirmitha D, Suresh DR. Significance of hs-CRP and Oxidative Stress as Early Novel Markers of Subclinical Atherosclerosis in Young Healthy Obese Males. J Biomed Sci and Res. 2010; 2(3):143-50.

Rachmi.C.N; Li. M; Baur, A.L. 2017. Overweight ang Obesity in Indonesia : Prevalence and risk factors_a literature review. Public Health Journal, 147 (2017) 20 - 29. www.elsevier.com/puhe

Paramesa S, Vijay R, Bekalc M, Kumari S, Pushpalathab KC. 2011. A Study on Lipid Peroxidation and Total Antioxidant Status in Diabetes with and without hypertension. Res. J Pharmaceutics Biological Chemical Sci. 2:32

Prihantini S, Jahari AB. 2007. Risk Factors of Obesity in School Children Age 6 - 18 Years in DKI Jakarta. Peneliti Gizi dan Makanan (2007); 30 (1): 32 - 24

Sanjur, D. dan Radriquez, M. 1997. Assesing Food Consumption-Selected Issues in Data Collection And Analysis. Cornell University

Sabitha K, Venugopal B, Rafi MD, Ramana KV. Role ofAntioxidant Enzymes in Glucose and Lipid Metabolism in Association with Obesity and Type 2 Diabetes. American Journal of Medical Sciences and Medicine. 2014; 2(1):21-

Taylor, AG and Vincent HK. 2006. Biomarker and Potential Mechanisms of Obesity induced Oxidant Stress in Humans. USA: International Journal of Obesity: London. 30 (3): 400

Weitner, Tin ;Inic Z; Jablan, J; Mario, Gabricevic; Ana-Marija, Domijan.2016. Spectrophotometric Determination of Malondealdehyde in Urine Suitable for Epidemiological Studies. JurnalCroat. Chem Acta 2016, 89 (1), 133-139. Faculty of Pharmacy and Biomedichemistry, University of Zagreb, Antekovacica 1.10000 
Werdhasari, Asri. 2014. Peran Antioksidan Bagi Kesehatan (The Role of Antioxidants for Health). Jakarta. Jurnal Biotek Medisiana Indonesia . Vol.3.2.2014: 59-68

WHO. 2016. Obesity and Overweight.www.who.int.diakses July 30, 2018

Wibowo, Tommy. 2013. Gambaran Kadar Malondialdehid dalam Urin Perokok dan Bukan Perokok pada Mahasiswa FKIK UIN Syarif Hidayatullah Jakarta pada Tahun 2013 (Overview of Malondialdehyde Levels in Smoker and Non-Smoker Urine in FKIK Students of Syarif Hidayatullah State Islamic University in Jakarta in 2013). Thesis. The Faculty of Medicine and Health Science, UIN Jakarta 